\title{
Grzegorz Markowski
}

Uniwersytet Ślaski

\section{KOMUNIKACJA \\ MIĘDZYKULTUROWA \\ A PROCES NAUCZANIA DOROSLYCH FRANCUSKIEGO JEZZYKA SPECJALISTYCZNEGO JAKO OBCEGO}

\section{Inter-Cultural Communication and the Process of Teaching Specialist French to Adults}

\begin{abstract}
The paper presents examples of techniques, strategies and activities by means of which a teacher of specialist French may improve the communicative competence level of their students, i.e. the communication skills and interculture competence. The suggestions presented will help the students to acquire the knowledge and skills necessary for functioning in the contemporary multicultural society. The aim is to prepare students for professional life by teaching them the correct use of specialist French in the institutions they are going to work for in the future.
\end{abstract}

\section{Wstęp}

W artykule zaprezentowane zostana przykłady technik, strategii i innych działań, którymi nauczyciel francuskiego języka specjalistycznego może podwyższyć poziom kompetencji komunikacyjnych swoich uczniów, czyli sprawności właściwego porozumiewania się. Przedstawione propozycje pomogą uczniom w zdobywaniu wiedzy i umiejętności niezbędnych do funkcjonowania we współczesnym społeczeństwie multikulturowym.

Chodzi o przygotowanie do życia zawodowego, tzn. o nabywanie przez uczniów kompetencji poprawnego posługiwania się francuskim językiem specjalistycznym jako obcym w instytucjach, w których będą w przyszłości pracować. 


\section{Relacje międzykulturowe}

Język stanowi podstawę kultury, więc należy odpowiednio przygotować uczniów do komunikacji międzykulturowej (konfrontacji, relacji, kontaktów, negocjacji), czyli do porozumiewania się w przyszłości ze swoimi współpracownikami. Rozwój współpracy międzynarodowej i globalizacja wszystkich dziedzin życia stwarza potrzebę przygotowania ludzi do kontaktów z innymi kulturami i sposobami życia. Ciagłe zmiany polityczne, ekonomiczne, społeczne oraz postęp techniki sprawiaja, że obecnie kontakty między kulturami są codziennościa.

Nauka języka obcego jest nie tylko przyswajaniem obcej mowy, ale także procesem przyswajania nowej kultury, nowej tożsamości. Zdaniem W. Miodka „Człowiek musi współżyć z innymi ludźmi, wchodzić w różne interakcje i szanować określone wzorce kulturowe. (...) Najbliższe otoczenie uczącego się powinno być dla niego podstawowym źródłem informacji, które wzbogaca jego wiedzę i tworzy różne, konieczne do życia umiejętności i zachowania" (2009: 42).

$\mathrm{Na}$ rynku pracy wzrasta zapotrzebowanie na bardzo wykwalifikowanych i mobilnych pracowników pod względem językowym i międzykulturowym. „Pracownicy coraz częściej tworza zespoły ponadnarodowe, międzykulturowe $\mathrm{i}$ interdyscyplinarne. Wszystko to wymaga dobrze zorganizowanej pracy zespołowej i zdolności negocjacyjnych. Systematycznie rośnie zapotrzebowanie na pracowników, którzy mają coraz wyższe kwalifikacje i umiejętności” (Modrzycka, 2009: 94). Polacy znający w stopniu zaawansowanym francuski język specjalistyczny (np. język handlowy) mają duże szanse na zatrudnienie $w$ instytucjach $z$ kapitałem francuskim, co sprawia, że będą współpracować z osobami, których językiem ojczystym jest język francuski.

Według D. Matsumoto i L. Juang ,nasze interakcje z innymi, sposób, w jaki je spostrzegamy, a także to, jak z nimi współpracujemy - wszystkie te obszary ulegają wpływowi kultury, w której żyjemy. Przyswoiliśmy sobie konkretne sposoby zachowywania się, spostrzegania i działania, zakorzenione w naszym wychowaniu i środowisku kulturowym. Może się nam wydawać, że przedstawiciele wszystkich kultur powinni się zachowywać i odnosić do siebie w taki sam sposób, jednakże to, co sprawdza się w jednej kulturze, często nie znajduje zastosowania w innych grupach kulturowych" (2007: 467).

Zgodnie z najpopularniejszą oraz najogólniejszą klasyfikacją grup społecznych w socjologii i psychologii społecznej, zaproponowaną przez M. B. Brewer’a i R. M. Kramer'a (1985: 219-243) grupy można podzielić na dwie kategorie:

- grupę własna,

- grupę obca.

Wskazanie różnic między poszczególnymi grupami nie stanowi większego problemu. A mianowicie relacje $z$ grupa własną oparte są na bliskiej znajomości, zaufaniu, przyjaźni, dążeniu do wspólnego celu, wspólnym zainteresowaniom. Chodzi więc o osoby nam bliskie. Z kolei relacje z grupą obcą charakteryzują się obojętnością, brakiem poczucia bliskości, pewną rezerwą. 
W społeczeństwie multikulturowym, bardzo często bywa tak, że cudzoziemców uważa się za osoby obce. Należą więc one do drugiej z wymienionych grup, więc do grupy osób, której się boimy ze względu m.in. na różnice kulturowe, na barierę językową czyli ze względu na ich obcość. Zdaniem D. Matsumoto i L. Juang (2007: 467), podział na w/w grupy występuje we wszystkich kulturach i społeczeństwach. Jednak często zdarza się tak, że w poszczególnych społeczeństwach istnieją różne kryteria budowania relacji międzyludzkich. Jak więc zmniejszyć dystans między poszczególnymi grupami? Mamy tutaj na myśli kreowanie w procesie nauczania „dobrych relacji” między Polakami uczącymi się francuskiego języka specjalistycznego, na przykład francuskiego języka biznesu, i Francuzami jako pracownikami firm, czyli z osobami, z którymi Polacy współpracują lub będą współpracować w przyszłości. Z pewnością m.in. odpowiednio wysoki poziom kompetencji językowej ma ogromny wpływ na budowanie takich relacji. Należy podkreślić, że zagraniczni przedsiębiorcy coraz bardziej doceniają atuty polskiej gospodarki. Według danych opublikowanych w Internecie 30 kwietnia 2009 roku nasz kraj awansował z 15. na 5. miejsce w najnowszym rankingu atrakcyjności inwestycyjnej PricewaterhouseCoopers. W zestawieniu 20 państw wyprzedzają nas jedynie Chile, Bułgaria, Malezja i Chiny (http:/ finanse.wp.pl/kat,104762,title,Polska-bardziej-atrakcyjna-dla firm,wid,11083301,wiadomosc.html?ticaid=17f14). Coraz więcej firm lokuje swój kapitał w naszym kraju, co sprawia, że na rynku pracy rośnie zapotrzebowanie na osoby władające językiem francuskim z dziedziny biznesu, a szczególnie na osoby znające przynajmniej dwa specjalistyczne języki obce.

Opanowanie sprawności językowych bez wątpienia ułatwia komunikację międzykulturowa. Kowalikowa (1997) w artykule zatytułowanym Kreatywność jezy/ka ucznia w szkolnej edukacji polonistycznej przedstawia pojęcie ,kompetencji komunikacyjnej” jako teoretyczną i praktyczną gotowość oraz zdolności danej jednostki do pełnienia roli nadawcy i/lub odbiorcy różnorodnych treściowo, formalnie i funkcjonalnie komunikatów, przekazywanych i przyjmowanych w rozmaitych sytuacjach, determinowanych typem kontaktu pomiędzy partnerami, okolicznościami zewnętrznymi. Kowalikowa (1997) jest zdania, że im wyższy poziom zdolności widzenia wymienionych czynników (modyfikatorów zachowania się językowego danej jednostki), tym szerszy zakres owej kompetencji, większa szansa jej posiadacza na skuteczne przekazywanie i przyjmowanie danej informacji. Aby ograniczyć tzw. „,szok kulturowy” należy zmniejszyć dystans społeczny, na który jest narażony każdy człowiek na przykład wyjeżdżający za granicę. Możemy stwierdzić, że im wybrane kultury, z których jedna jest własna o druga obca, sa podobne do siebie, tym bardziej człowiek doświadcza poczucia zrozumienia, bliskości oraz sentymentu. To powoduje mniejszy strach przed „czymś obcym”.

W artykule pt. Obcośc $i$ perspektywa wlasna w nauczaniu interkulturowym powołując się na O. Schäffter’a Piekarz stwierdza, że „obcość możemy zdefiniować jako rezultat stosunku zetknięcia się, zderzenia dwóch kultur, podczas którego dochodzi do rejestracji nowych, nieznanych jakości, fenomenów” (2004: 80). Czytamy także, że „obcość wypływająca z kontaktu z innym językiem i jego kulturą jest wywołana na płaszczyźnie własnych powiązań społeczno-historycznych oraz oso- 
bistej i socjalnej identyfikacji, jak też tożsamości kulturowej. Przy zetknięciu się ze zjawiskami obcokulturowymi dochodzi do „zderzeń dwóch światów”: różnych koncepcji, schematów i tradycji odbioru oraz postrzegania i definiowania rzeczywistości” (Piekarz, 2004: 80).

W procesie nauczania francuskiego języka biznesu ważne jest więc m.in. przekazywanie/dostarczanie uczniom wiedzy związanej z kulturą danego obszaru językowego oraz korzystanie z odpowiednich pomocy dydaktycznych.

\section{Nauczanie komunikacji międzykulturowej}

W nauczaniu języków obcych istotny jest dostęp do materiałów do nauki języka francuskiego zawierających treści kulturowe, ale także odpowiednie przygotowanie nauczyciela, który nauczając kultury danego obszaru językowego, oprócz perfekcyjnej znajomości języka obcego musi być także bardzo dobrze zorientowanym w kulturze danego narodu, posiadać wiadomości kulturowo-cywilizacyjne na temat obszaru nauczanego języka.

Znajomość zwyczajów, tradycji, różnych form zachowania się, wyrażania się, geografia, historia danego kraju oraz wiedza o muzyce, sztuce, literaturze danego kraju stanowia bardzo ważne elementy nauczania kompetencji językowej. Wysoki poziom owej wiedzy bez wattpienia pomaga w znacznym stopniu w komunikacji międzykulturowej.

W naszym kraju materiałów do nauczania francuskiego języka handlowego nie ma zbyt dużo.

W Polsce nauczyciel może skorzystać z kilkunastu podręczników do nauczania wspomnianego języka, na przykład:

- "Affaires à suivre» (Bloomfield i Tauzin, 2001, Paris : Hachette Livre);

- "Affaires à faire Pratique de la Négociation d'Affaires en Français 》 (Szilagyi, 1997, Grenoble: Presses Universitaires de Grenoble);

- «Commerce/Affaires» (Pou i Sanchez, 1993, Paris : CLE International);

- "Faire des Affaires en Français » (Sanchez Macagno i Corado, 1997, Paris : Hachette Livre);

- "Le Nouvean French for Buisness Le Français des Affaires » (Le Goff, 2000, Paris : Éditions Didier);

- "Le français de la Communication Professionnelle »(Danilo, Penfornis i Lincoln, 1993, Paris : CLE International);

- «Le français des affaires par la Vidéo (Le Ninan, 1993, Paris : Éditions Didier);

- "Le francais de l'entreprise » (Danilo i Tauzin, 1990, Paris : CLE International).

Zaprezentowane $\mathrm{w}$ nich elementy kulturowe sa jednak niewystarczające. Brakuje między innymi autentycznych tekstów, na podstawie których studenci mieli by możliwość zapoznania się w sposób wystarczający z realiami obowiązującymi w firmach. W wymienionych podręcznikach kładzie się nacisk głównie na terminologię specjalistyczną oraz na kontekst, w którym ona funkcjonuje. Zdecydowana większość zaproponowanych tekstów stanowi zbiór spreparowanych lub pól-autentycznych pomocy dydaktycznych. Problem stanowi także dostęp do słowników 
polsko-francuskich i francusko-polskich z dziedziny handlowej. Możemy śmiało stwierdzić, że brakuje słowników opracowanych w sposób szczegółowy. Możemy zaproponować «Francusko-polski słownik tematyczny EKONOMIA» (Gillmann i Verrel, 2002), słownik, który możemy kupić w Polsce, oraz słowniki, które są do kupienia we Francji, na przykład « Dictionnaire d'apprentissage du français des affaires » (Binon, 2005), « Dictionnaire d'économie et des faits, économiques et sociaux contemporains » (Bialès, 1999).

Nauczyciel może jednak poradzić sobie z tym problemem, proponując uczniom autentyczne teksty (fachowe, informacyjne, publicystyczne), opracowania, dokumenty handlowe i biznesowe, artykuły z prasy, które można bez większego problemu znaleźć na przykład w Internecie. Nauczając francuskiego języka handlowego nauczyciel może, a nawet powinien nauczać kultury. Powinien przygotować takie ćwiczenia oraz wybrać takie pomoce dydaktyczne, aby oprócz kompetencji językowych uczniowie poznawali kulturę społeczeństwa (grupy), w której w przyszłości będą pracować.

Mając na myśli podnoszenie świadomości kulturowej nauczyciel powinien proponować ćwiczenia polegające nie tylko na przyswajaniu terminologii należącej do zbioru słownictwa francuskiego języka specjalistycznego, ale także na wskazywaniu różnic kulturowych, omawianiu tradycji i zwyczajów praktykowanych przez środowisko, w którym w przyszłości mogą pracować jego uczniowie. Powinien przekazywać „całe bogactwo wiedzy o życiu danej społeczności, jej wartościach, postawach i problemach" (Strzałka, 2004: 8).

Sukces w komunikowaniu się z cudzoziemcem osiąga się dzięki kompetencjom językowym oraz kompetencji międzykulturowej. Nauczyciela zadaniem jest więc:

- doskonalenie znajomości języka obcego, aby studenci mogli posługiwać się nim praktycznie;

- przekazywanie swoim uczniom wiedzy o kulturze rodzimej i obcej, uwzględniając szczególnie to co go fascynuje lub dziwi w danej obcej kulturze;

- wypracowanie umiejętności wyciagania odpowiednich wniosków oraz pozytywnego nastawienia do innych kultur;

- rozwijanie umiejętności radzenia sobie w kontaktach międzykulturowych.

Należy przekazać studentom specjalistyczną wiedzę, umiejętności i postawy, które będą im potrzebne w życiu zawodowym. Nauczyciel powinien zachęcać studentów do nawiązywania, rozwijania, podtrzymywania kontaktów z osobami reprezentującymi inne kultury. Sam kontakt z cudzoziemcem jest czynnikiem doskonalającym kompetencję językową. Im częściej taki kontakt ma miejsce, tym mniejsze nieporozumienia wynikające $z$ różnic językowych i kulturowych. Należy, więc organizować spotkania z użytkownikami danego języka obcego, zapraszać cudzoziemców na zajęcia. Wymiany międzyuczelniane studentów odgrywają także bardzo ważną rolę, ponieważ nawiązywanie kontaktów z rówieśnikami z innej kultury poszerza ich wiedzę językową i kulturoznawczą. Staże zawodowe są również 
wyśmienita okazją do doskonalenia kompetencji językowej oraz do poznania elementów obcej kultury.

Podkreślić więc należy istotną rolę autentyczności w procesie doskonalenia kompetencji językowej w komunikacji międzykulturowej w danym języku.

Aby doskonalić kompetencje językowe nauczyciel może zaproponować studentom zadania do zrealizowania, których głównym celem jest akwizycja nowego słownictwa $z$ dziedziny handlowej oraz jego zastosowanie w odpowiednim kontekście specjalistycznym, na przykład:

- na podstawie listy wybranych słów z tekstu, studenci próbują podać ich definicje $\mathrm{w}$ języku francuskim;

- utworzyć kilka zdań z wyrazami z proponowanego dokumentu;

- według listy kluczowych słów zaproponować pełną treść tekstu;

- podkreślić w tekście kluczowe słownictwo i ułożyć z nim zdania;

- zastapić wskazaną leksykę synonimami lub antonimami oraz ułożyć z nimi zdania;

- wskazać w proponowanym tekście słownictwo typowo specjalistyczne oraz należące do języków: ogólnego i specjalistycznego, ułożyć zdania w przypadku leksyki należącej do obu języków studenci proponują z każdym ze słów kilka zdań, w których uwzględniają wszystkie możliwe konteksty, w których dane słowo funkcjonuje;

- wypisać leksykę, która została zapamiętana po przeczytaniu tekstu;

- po kilkukrotnym przeczytaniu na przykład listu lub poczty internetowej dotyczącej dziedziny handlowej, studenci próbują odtworzyć jego treść;

- streścić dokument na przykład w 10 zdaniach.

Powyższe propozycje ćwiczeń pomagają zapamiętać i/lub utrwalić słownictwo danego tekstu oraz kontekst, w którym ono funkcjonuje.

Oczywistym jest, że nauczając leksyki nauczyciel powinien zadbać także o jej praktyczne wykorzystanie w wypowiedziach ustnych i pisemnych. Ma to na celu głównie przygotowanie studentów do komunikacji językowej we francuskim języku handlowym, nauczanie strategii oraz wypracowanie zachowań komunikacyjnych. W tym przypadku moglibyśmy zaproponować na przykład ćwiczenia:

- gdzie uczniowie posługując się działaniami językowymi i pozajęzykowymi muszą osiagnać wyznaczony przez nauczyciela cel; przykładem może być opracowanie reklamacji zakupionego produktu;

- w których uczniowie mają możliwość współdziałania w zespole, na przykład przygotowanie oraz przeprowadzenie wywiadu;

- gdzie uczniowie mają możliwość podejmowania decyzji indywidualnie i/lub grupowo, na przykład fikcyjne inwestycje na giełdzie;

- w których uczniowie maja za zadanie rozwiązanie jakiegoś problemu, na przykład jako właściciele firm studenci wybieraja jeden z wariantów ratujący ich firmy przed bankructwem, oraz zadania umożliwiające studentom wymianę poglądów, interpretację, porównania, negocjacje.

Nauczanie języków obcych powinno się odbywać w sprzyjającej do tego atmosferze oraz w odpowiednio przygotowanych do tego procesu miejscach, mamy 
na myśli na przykład atelier konwersacji. Ważny jest również stały dostęp studentów do sali informatycznej i do mediateki, aby była możliwość wykorzystania w procesie nauczania technik medialnych takich jak na przykład sieci internetowej, odtwarzaczy DVD, MP3, wideo, telewizji satelitarnej. Istotne jest wykorzystanie materiałów wizualnych i audytywnych w celu pobudzania u uczniów skojarzeń, wyobrażeń, refleksji.

Z kolei zdolność obsługi komputera, korzystania z Internetu i rozwijanie kompetencji medialnej łączy się z rozwijaniem kompetencji zawodowych.

Różnego rodzaju programy on-line, związane z językiem francuskim, korespondencja internetowa, oryginalne teksty, materiały do samodzielnej lektury, stanowią czynnik motywujący do nauki wspomnianego języka, do zainteresowania się kulturą Francji, a w konsekwencji do ułatwienia komunikacji międzykulturowej.

\section{Wnioski}

Podsumowując, należy podkreślić, że w obecnych czasach, gdy kontakty między kulturami są codziennością bardzo ważne jest nauczanie języka, w naszym przypadku, francuskiego języka specjalistycznego, oraz odpowiednie przygotowanie uczniów do kontaktów z obcą kulturą. W nauczaniu ważna jest m.in. postawa nauczyciela.

To nauczyciel decyduje o doborze odpowiedniego podręcznika oraz niezbędnych pomocy dydaktycznych. Proponuje ćwiczenia, techniki, strategie, których głównym celem powinno być poszerzenie kompetencji językowych uczniów, poznanie obcej kultury: tradycji, atrakcji turystycznych, systemu politycznego, życia zawodowego, przekonań, wartości, stosunków na przykład ekonomicznych, politycznych między dwoma krajami, w tym przypadku między Polską i Francją. Należy podkreślić fakt, że im więcej studenci wiedzą o obcej kulturze, tym bardziej są tolerancyjni. Atrakcyjność obcej kultury stanowi czynnik motywujący do pogłębiania znajomości języka obcego. Poza tym nauczyciel powinien, tak często jak to tylko możliwe, umożliwiać dostęp uczniów do wszelkich możliwych udogodnień, które pomoga im w zdobywaniu wiedzy na temat języka francuskiego oraz kultury Francji i państw, w których języka francuskiego używa się na co dzień.

\section{BIBLIOGRAFIA}

Binon, J. 2005. Dictionnaire D’apprentissage du français des affaires. Paris : Didier. Bloomfield A., Tauzin B. 2001. Affaires à suivre. Paris : Hachette Livre.

Brewer, M. B., Kramer, R. M. 1985. „The psychology of intergroup attitudes and behavior". Annual Review of Psychology 36: 219-243.

Danilo M., Penfornis J.-L., Lincoln M. 1993. Le français de la Communication Professionnelle. Paris : CLE International.

Danilo, M., Tauzin B. 1990. Le français de l'entreprise. Paris: CLE International. Gillmann, B., Verrel, M. 2002. Francusko-polski stownik tematyczny EKONOMLA. Warszawa: Wydawnictwo Naukowe PWN. 
Kowalikowa, J. 1997. „Kreatywność języka ucznia w szkolnej edukacji polonistycznej”. [w:] Ożdżyński J., Rittel T., Sprawności jesyykowe, Kraków.

Le Goff C. 2000. Le Nonveau French for Business Le Français des Affaires. Paris: Éditions Didier.

Le Ninan C. 1993. Le français des affaires par la Vidéo. Paris : Éditions Didier.

Matsumoto, D., Juang, L. 2007. Psychologia miedryykulturowa. Gdańsk: Gdańskie Wydawnictwo Psychologiczne.

Miodek, W. 2009. „Elementy regionalne a tożsamość studiującego na zajęciach języka obcego". (w) Grabara, M. Wybrane zagadnienia z. metodyki nauczania jezyków obcych. Częstochowa: Wydawnictwo Politechniki Częstochowskiej.

Modrzycka, I. 2009. „Kompetencje językowe i społeczne inżynierów w aspekcie wymagań europejskiego rynku pracy". (w) Grabara, M. Wybrane zagadnienia z. metodyki nauczania jezykeów obcych. Częstochowa: Wydawnictwo Politechniki Częstochowskiej.

Piekarz, M. 2004. „Obcość i perspektywa własna w nauczaniu interkulturowym”. Neofilolog 24: 80-84.

Pou G., Sanchez M. 1993. Commerce/Affaires. Paris : CLE International.

Sanchez Macagno M.-O., Corado L. 1997. Faire des Affaires en Français. Paris: Hachette Livre.

Strzałka, A. 2004. „Zintegrowane nauczanie jezzyka i kultury”. Neofilolog 25: 6-9.

Szilagyi, E. 1997. Affaires à faire Pratique de la Négociation d'Affaires en Français. Grenoble: Presses Universitaires de Grenoble.

http:// finanse.wp.pl/kat,104762,title,Polska-bardziej-atrakcyjna-dla firm, wid,11083301, wiadomosc.html?ticaid=17f14 DW 30.04.2009. 